\title{
EL AÑ $O$ DE RICARDO AND THE DEGENERATION OF EUROPE
}

\author{
Remedios Perni Llorente
}

\author{
Universidad de Murcia (Spain)
}

\begin{abstract}
El año de Ricardo is the title of Angelica Liddell's take on William Shakespeare's Richard III. Through both her rewriting and mise en scène, the irreverent Spanish playwright and performer presents Shakespeare's infamous character as a prototype of an overambitious, ruthlessly cynical monster, a foul, appalling brute. Ricardo stands for Hitler and for all the villains. (S)he is a baroque spectre, an anamorphic presence which pushes the limits and transforms across time, evolving from a top executive to a president; from a wannabe writer to a doctorate honoris causa. Ricardo's body undergoes a degenerative process and so does his/her cynical behaviour. Perverse capitalism speaks through Ricardo, a clear embodiment of the corrupt. In this sense, the villainy of Richard III, via Liddell, has been compared to corruption scandals which have occurred in Spain. As a matter of fact, premiered in 2005, the play has been repeatedly onstage since the financial crisis was announced, probably because it provides an opportunity to criticise the people and policies at the heart of the meltdown. This paper focuses on the Shakespearean motifs that build Liddell's play, paying special attention to the anachronistic twists that serve the purpose of revealing Richard/Ricardo's degeneration in a degenerate Europe.
\end{abstract}

Keywords: William Shakespeare, Angélica Liddell, performance, appropriation, theatre, European crisis.

\section{Resumen}

El año de Ricardo es el título de la versión que hace Angélica Liddell de Richard III de William Shakespeare. A través de su reescritura y su puesta en escena, la irreverente dramaturga e intérprete española presenta al infame personaje como un prototipo de monstruo avaricioso y cínico, un bufón, una bestia horrorosa. Ricardo representa a Hitler y a todos los villanos. Él/ella es un espectro barroco, una presencia anamórfica que excede los límites y se transforma a lo largo del tiempo, pasando de ejecutivo a presidente, de aspirante a escritor a doctor honoris causa. El cuerpo de Ricardo sufre un proceso degenerativo y también lo hace su cínico comportamiento. El capitalismo perverso habla a través de Ricardo, obvia encarnación de los corruptos. En este sentido, la villanía de Richard III, a través de Liddell, ha sido comparada con escándalos de corrupción habidos en España. De hecho, estrenada en 2005, la obra ha permanecido en escena desde que se anunció la crisis económica, probablemente porque ofrece una oportunidad para criticar a las personas y las políticas responsables de la depresión. Así pues, el presente artículo se centra en los motivos shakesperianos que conforman la obra de Liddell, poniendo especial 
atención en los giros anacrónicos que ponen de manifiesto la degeneración de Richard/Ricardo en una Europa degenerada.

Palabras clave: William Shakespeare, Angélica Liddell, performance, apropiación, teatro, crisis europea.

Richard III has become one of the most recurrent characters to discuss today's challenging political landscape on a stage. Richard provides the space both to discuss human evil and abuse, and to explore the roots of (institutional) violence. Nonetheless, among the great variety of productions based on Shakespeare's tragedy in this context, it is possible to distinguish at least two main approaches to the legendary king: history-based nostalgia for Richard's epic; and, most interesting, an attempt to transgress such feeling of nostalgia through a rupture with any pastness, pushing Richard III out of time and place to, ironically, criticise the present. This paper aims to focus on this second tendency, specifically on Angelica Liddell's rewriting, El año de Ricardo (The Year of Richard), and the anachronistic twists of such a production that serve the purpose of revealing Richard/Ricardo's degeneration within the context of European mainly Spanish-political decay.

Fredric Jameson has shed light on the idea of nostalgia pointing out that the nostalgic relation with the past does not usually involve a rigorous historical analysis. Most of the times, the past depicted in nostalgic terms is characterised by vagueness and pastiche (21). The past is blurred, and so is the recent past, which usually merges with a nebulous idea of the present. Moreover, the fixation with an idealised present may result in "nostalgia for the present", a concept explained by Courtney Lehmann as "an affective paradox that generates complacency with the way things are" (72). ${ }^{1}$ This has been the case of many theatrical productions of Richard III in recent years. Both costume dramas and hybrid or modernised versions of the play make the spectator embrace a time in which, regardless of the historical events, the past is embellished, made legendary, reified for the gaze. Because many spectators are thirsty for a heightened sense of reality, something 'real' needs to be attached to the fictional character to be experienced and understood; most of the times, such 'real' components depend on History, past or contemporary. However, aesthetic vagueness, far from historical accuracy, results in vague criticism on what is shown. Reality and fiction intermingle, they contaminate each other, and idealization arises, which implies "a feeling of duty to the past" and to its "mythical qualities" -Susan Bennett's definition of nostalgia (1-17).

A good illustration of the merging of fiction and reality, past and present, through nostalgia is the image of the remains of Richard III, seen on television last 26 March 2015, when he was reburied at Leicester Cathedral after having been found under a parking lot. It was a celebrated event: there were processions, special coverage and television programs. Experts, scientists, historians, actors

${ }^{1}$ Lehman writes are in italics: her emphasis. 
and politicians gathered to talk about "who Richard really was, and what his place in British history should now be" (Channel 4, 2015). The traces of the past had literally reappeared, and there arose a great interest in the times of battles, royalty and epic. There were discussions on Tudor propaganda against Richard III, now that it was supposedly proven that he was vilified through Shakespeare's drama. The research on the king's skeleton had revealed that describing this king as "a monster great deformed" was rather an exaggeration of a simple scoliosis. And then, everything concerning Richard's myth might have been exaggerated as well. People wanted to know 'the truth', and honour the medieval king.

Interestingly, the 'real remains' of Richard were repeatedly examined through the lens of the literary account (comparisons, references to Shakespeare in press articles, etc.). Put in perspective, there is no doubt that without Shakespeare, the interest in the archaeological discovery would not have been so intense. In fact, a theatrical production at the Cockpit Theatre (London) was launched to coincide with the planned re-burial of Richard's remains. And, even more remarkable, it was Benedict Cumberbatch, best known for his television work (Sherlock), who read Dame Carol Ann's poem in tribute to Richard III during the burial ceremony at Leicester. ${ }^{2}$ It was not a random choice, as Cumberbatch is believed to be the king's late second cousin, sixteen times removed. But the story does not end here: the late cousins, their past and present, the legendary character and the actor, all these ingredients will be mixed in a new take on Richard III for BBC's new Hollow Crown series in 2016. It seems to be one of Shakespeare's superpowers: his characters have evolved throughout time to enter reality and go back to fiction. This television film is planned to be a costume drama, keeping most of Shakespeare's text untouched. Like other (film or theatrical) adaptations also featuring television celebrities, such as the recent Sueños y visiones del Rey Ricardo III (performed at the Teatro Español, Madrid, in November 2014), this series is aimed at reviving medieval aesthetics and sticking to the psychological perspective on Richard, more than his deplorable political strategies.

The suspension of the distinction between fiction and reality attracts the audience not only when the otherness of the past is addressed 'aesthetically', but also when this past is conveniently relocated at pseudo-present times, showing contemporary history through the Shakespearean lens. In the case of Richard III, such historical relocation has been said to be a perfect vehicle to criticise contemporary politics. In an interview with Kevin Spacey, who played Richard III on the London stage in 2014, the actor pointed out that the theatrical production talked about "dictators around the world", and was inspired by Muammar Gaddafi and how people responded to him in the Arab Spring (Keith Perry 2014).

\footnotetext{
${ }^{2}$ See BBC News: Actor Cumberbatch to Read Poem at Richard Reburial. BBC News. Web. 24 Mar. 2015. <http://www.bbc.com/news/uk-englandleicestershire-32040692>.
} 
Also Martin Freeman (Dr. Watson in Sherlock, Bilbo in The Hobbit) has recently played a modernised and critical Richard in a production set in the 1970s, where Britain has undergone a military coup. Freeman incarnates a businessman, and the play offers a "peculiarly bloodthirsty display of office politics" which might remind us of Wall Street speculation, and prototypical sociopaths (BBC News, 2014).

Nonetheless, the criticism launched by this modern version, based on the threat of a military coup against the Labour Prime Minister Harold Wilson in the mid-seventies, directs the audience's attention to Britain's 1970 "Winter of Discontent", a time of widespread strikes organised by the public sector trade unions demanding larger pay rises. Although deriving from Richard III, this catchphrase is known to have been deployed by the right-wing press to slander the strikes, and was used repeatedly during Margaret Thatcher's government to remind the population of the dangers of left-wing politics. Most remarkable, in September 2008, BBC News made use of the same expression, "then was the winter of our discontent," to talk about trade unionists who were meeting "against a backdrop of government demands for pay restraint," and planning for "synchronised strike action that might echo those weeks in early 1979 when the dead went unburied and school children feared they'd have to cross picket lines to get to their exams" (Perkins 2008). As Jonathan Dollimore argued, "what the plays signify, how they signify, depends on the cultural field in which they are situated" (viii).

It was probably the film adaptation Richard III directed by Richard Loncraine and starring Ian McKellen in 1995 that triggered most of the politically critical film and theatrical productions based on Shakespeare's play in the twenty-first century. Based on a stage production directed by Richard Eyre, which also starred McKellen, it re-contextualised the play's events to a fascist Britain in the 1930s. "When you put this amazing old story in a believable modern setting" -McKellen points out- “... it will hopefully raise the hair on the back of your neck, and you won't be able to dismiss it as just a movie or, indeed, as just old-fashioned Shakespeare" (Percy and Reynolds, Stagework). Indeed, the idea of relating Richard III to the rise of totalitarianism and dictatorship has influenced the work of many artists trying to explore the roots of political injustice at present. But, as it has been observed, such exploration is sometimes too restrained: it does approach political matters but in such a way that these matters still belong to a different level of commitment, as if alien to immediate and unmediated-reality.

Nevertheless, there are ways of comprehending the past (Shakespeare) through the epistemological lens of the present to attack Richard III's villainy as a fundamental part of today's banality of evil within the European democratic institutions. Angelica Liddell's El año de Ricardo provides evidence for that. Indeed, the previous political approaches to Richard III onstage and on screen play their part in Liddell's rewriting of the Shakespearean drama. Ian McKellen's fascist characterization or the colourful grotesqueness of Lawrence's Olivier version are combined by Liddell and taken to the extreme. At the same 
time, Liddell tries to break with inherited tradition and make Richard III timeless and stubbornly present. He is not far or past, he is here and now. Richard III is a product of capitalism, the embodiment of inequality and abuse, the corruption of democracy and thus proof that we should distrust authority. In a way, El año de Ricardo can be seen as an attempt to use the theatre to subvert any authority. Whereas other adaptations focus on conflicts between good (governors) and evil (governors) -after all, Richard III loses the battle at the end of the play, handing over power to the next king-El año de Ricardo discusses power relations, as well as their constant degeneration within democracy. This is depicted in the Prologue to the play as "the despicable, hypocritical and murderous nature of power, however much we try to disguise it as democratic legitimacy" (Montero $5)^{3}$

How does Liddell deal with that and in what ways is her version different from others within the context of the economic crisis? Liddell transcends the binary logic (good/evil; male/female; past/present) and offers a preposterous Richard, a character out of time and place, capable of being transformed into a many-sided villain, re-imagined as everything that is dark and twisted within the world. The authenticity of a historical Richard is irrelevant here: it is the symbolism that counts.

There are only two characters in Liddell's production of Richard III: Ricardo, who is played by Angelica Liddell, and his companion Catesby, played by Gumersindo Puche. The king is attired in a colourful pyjama, while Catesby is dressed in black. Only Ricardo speaks, while Catesby remains silent. Ricardo's monologue is an uninterrupted political speech combining the Shakespearean text and Liddell's own comments; the result is a voice speaking without rest, delivering biting satire on personal complexes and totalitarian experiments. Meanwhile, the spectators listen, submitted to the implacability of Richard. We, the spectators, are like Catesbies waiting for the king to stop his soliloquy.

When interviewed about this work, Liddell states that she wrote it out of a necessity to speak about those who were governing the world at the beginning of the twenty-first century; about Bush, Blair and also Aznar (Avilés 2011). She wanted to denounce the illegitimate invasion of Afghanistan, depicting these politicians as dangerous buffoons who had abused democracy to fulfil their own personal ambitions, causing horrendous suffering. This was the starting point of a radical satire on issues as crucial as the corruption of the State, the irresponsibility of power and false democracy. Indeed, the central question of the play is the fact that economy is taking priority over democracy and justice nowadays. In this sense, Liddell's production has evolved theatrically over the years; premiered in December 2005, and written against the background of the

${ }^{3}$ All references to Liddell's text are my own translation into English. The original text is available at Archivo visual de Artes Escénicas.: El año de Ricardo. Universidad de Castilla La Mancha. Web. Nov. 2015. $<$ http://artesescenicas.uclm.es/archivos_subidos/textos/240/angelicaliddell_ricar do.pdf $>$. 
Iraq War, it has been on stage since then, not only via Atra Bilis -Liddell's theatre company- but also others. Atra Bilis produced El año de Ricardo for Cuarta Pared, Festival Escena Contemporánea (Madrid, 2007), Teatro ValleInclán (Madrid, 2007), Teatro Lliure (Barcelona, 2008), Teatro Alhambra (Granada, 2009), Festival D’Avignon (2010), Sala Ambigú (Valladolid, 2011), and Biennale Teatro (Venice, 2013), amongst other venues. Other theatre companies, such as Quasar Teatro, have also produced this play since 2012.

Due to its anachronistic symbolism, and its harsh criticism on capitalist politics, the play has continued to be relevant within the context of the housing bubble, the politics of austerity, the evictions and the social turmoil that have characterised Spain and other European countries since 2008. Especially in the case of Spain, and -as occurring to Prince Hal in Shakespeare's Henry IVcorruption has made the citizens "pay the debt [they] never promised." Greed, cronyism, corrupt leaders of banks, and corrupt politicians have caused a private loss later transferred to the public sector. While half a million families were losing their homes, and the Spanish unemployment figure rose to more than five million, a parallel society kept paying astronomical early retirements to executives, and fraud ran rampant. The private extravaganza moved in to nationalise Bankia in 2012, and wait for a bailout, whereas deep austerity was imposed on the population to stick to the eurozone's budget targets (De Barrón 2012). This is the background against which many spectators saw Liddell's play.

What makes El año de Ricardo different from other productions based on Richard III is its lack of nostalgia. There is no embellishment of the past, no battlefield, no uniform, and thus no epic. There is neither nostalgia for the present, nor presentist epic: Ricardo has little to do with the portrait of a psychopath in the leather jacket provided by The Royal Shakespeare Company, ${ }^{4}$ and is far from Martin Freeman's charismatic acting. The irreverent Spanish playwright and performer depicts and plays Shakespeare's infamous character as a prototype of an overambitious, ruthlessly cynical monster, a foul, appalling brute. Ricardo stands for all villains. (S)he is a baroque specter, an anamorphic presence which pushes the limits and becomes transformed across time, evolving into different materializations of wickedness. It is from a domestic setting that Ricardo destroys the world, giving orders and delivering his speeches without really getting involved in the reality of the world. He is sick and weak, and Catesby has to help him stretch his atrophied muscles. Body decay and political decay is the same thing in a world where only the capita (Latin word for 'head') seems to be intact, where only capitalism decides, no matter where or when. In Liddell's work, the notion of historical time and place is also in decay and challenged. Chronology is relativized by heterochrony (many times) and

\footnotetext{
${ }^{4}$ See the Royal Shakespeare Company Richard III trailer here: <https://www.youtube.com/watch?v=K9wzWYtYGBI>.
} 
anachrony (out of time), for instance through the references to different historical figures that bring a variety of time periods to the stage. ${ }^{5}$

At the beginning of Liddell's play, Ricardo says he has bought a flag belonging to Franco; this is a flag that displays the image of a boar. The 'boar' is an animal that is mentioned repeatedly in Shakespeare's tragedy, since various characters refer to Richard as the 'boar' throughout the play. This animal is Richard's heraldic symbol on his coat of arms, although Queen Margaret prefers to call it a 'hog' when insulting Richard: "elvish-mark'd, abortive, rooting hog" (Act 1, scene 3). Therefore, this animal constitutes a symbol of Richard's own animalism and abjection, an appreciation highlighted by the film director Richard Loncraine in his Hitler-like Richard III (1995) through decorated flags and uniforms. It is no surprise that soon after pronouncing the name of the Spanish dictator, Ricardo transforms into Hitler himself. He confesses that his "gut problems" were the cause of six million dead bodies in central Europe: "Due to a gut problem, / due to childhood trauma, / due to digestive disorders, / due to pancreas damage, / due to a nervous disorder, / six million skeletons in central Europe" (60). Throughout the play, Liddell highlights the idea that the personal is political and vice versa: "I want my private suffering to cause a general suffering!" (59).

Later in the play, Ricardo talks as a businessman who invests money in the arms industry. He refers cynically to the fact that he did not really kill his brother, but "just provided the money." "Bang! Goodbye, brother, goodbye. / I just provided the money. / I just paid the uniforms. / I am just a poor entrepreneur. / The deformed manage the money. / The strong use the arms" (60). He pours some water on his face to simulate tears.

But Ricardo is not only a Western arms investor; he is also a big fan of meat industries. Liddell's interpretation of Richard's famous words, "A horse, a horse! My kingdom for a horse!" (Act 5, scene 4, 7-10) is like this:

There is no better meat than horsemeat. A young horse. A recently killed horse [...] This is something I learned in Switzerland. They eat boiled horse at Christmas Eve while insulting the Romanians. They say that the Romanians get ill, that they get ill on purpose to be treated in their hospitals [...]. The Swiss have the misfortune to be near the East. The Swiss! [...] We aren't safe, Catesby, we aren't safe. (62)

As stated by various reports by healthcare associations and research teams (in Spain, for instance, Fundación de Estudios de Economía Aplicada and Asociación de Economía de la Salud, among others), since the beginning of the economic crisis and due to the austerity measures employed, the European health

\footnotetext{
${ }^{5}$ These two concepts have been borrowed from Mieke Bal's studies on preposterous History. See Bal, Mieke. Quoting Caravaggio, Contemporary Art, Preposterous History. Chicago: University of Chicago Press, 1999.
} 
systems have been failing to adequately meet the needs of vulnerable people. ${ }^{6}$ One of the consequences of scarcity and misinformation is xenophobia, a growing problem in Europe, with migrants often being made scapegoats for economic problems. ${ }^{7}$

Probably taking advantage of a similarly precarious state of affairs, Ricardo decides to found a political party that may remind the spectator of any of the FarRight-Wing parties rewarded with seats in the European Parliament in recent years (the Front National in France, the National Democratic Party in Germany, or the Golden Dawn in Greece, just to mention a few):

I ask for a political party

I just ask for a political party.

I have paid your uniforms,

I have lent my factories,

my warehouses for your dirty business

[...]

I don't care about fucking ideology.

I am here because I don't know anything about politics.

Politics are powerless against economy.

[...]

It is necessary to take advantage of the miseries of those poor democrats,

Their credulity, their anger, their fear,

That mixture of ignorance and prosperity that characterises them

The working class is more conservative than ever before.

$[\ldots]$

We will feed the worker's rage with racism. (66-67)

Ricardo shouts at the audience like an illuminated maniac, listing the names of infamous twentieth-century 'politicians':

\footnotetext{
${ }^{6}$ Sevillano, Elena G. "10.000 millones menos para sanidad”. El País. Web. 14 Mar.

<http://politica.elpais.com/politica/2015/03/14/actualidad/1426369300_405355.h tml $>$.

${ }^{7}$ Doctors of the World: Austerity and Xenophobia Creating Barriers to Health Care in Europe. Doctors of the World. Web. 9 Apr. 2013. $<$ http://doctorsoftheworld.org.uk/blog/entry/austerity-and-xenophobia-creatingbarriers-to-healthcare-in-europe $>$.
} 
Franco hugging Hitler,

Franco hugging Eisenhower,

Franco hugging Nixon.

I know that this is not the same thing,

I am not an idiot,

I know that an American president can't be compared

to a dictator,

Legitimate - illegitimate

Legitimate - illegitimate.

That is why I am asking for a party. $(68)^{8}$

Later, Ricardo expresses his wish to be a writer. He lets us know that his violence is rooted in his lack of talent. His hate and fear of the written word makes him remark: "the writers must be the first to fall", and "somehow, it is necessary to deteriorate the language", "the more precarious the language, the more difficult to articulate thoughts" (85).

Ricardo also asserts "what is nice about the poor is that they aren't real." And, then, after having exterminated the poor, after having exploited their countries and bodies, "if we want to win the elections again, the economy must prevail over the dead"(91). This statement becomes quite significant within the context of the economic crisis in Europe, where the number of suicides has increased dramatically due to evictions, unemployment and scarcity. Ricardo's response is: "We will hide the suicides, of course!" (92).

Towards the end of the play, Ricardo has a nightmare. Three spectral dead children (the equivalent to Richard's murdered nephews in Shakespeare's play) approach his bed to blame him for their sad lives and miserable deaths: "I was carrying bricks, and I was hungry. Then Ricardo came to kill the tyrant, and he killed the tyrant and killed us all" (107). This scene includes both heterochronic and heterotopian elements, since it conveys the image of the ghostly children seen through a reproduction of Nick Ut's iconic photograph of the naked children running away from napalm in 1972 Vietnam. Simultaneously, Ricardo's monologue is referring to EU and US interventionist policies, to 'guarantee' democracy across borders, as well as to economic interventionism in Europe. Finally, as a result of his villainy, Ricardo is awarded a Doctor Honoris Causa. What Angelica seems to tell the spectator, through this deviation from Shakespeare's plot, is that villains are perfectly adapted to contemporary societies, that their acts are considered 'normal' by a vast majority of people, and

\footnotetext{
${ }^{8}$ This part of the soliloquy can be seen on YouTube:

$<\underline{\text { https: } / / \text { www.youtube.com } / \text { results? search query }=\mathrm{el}+\mathrm{a} \% \mathrm{C} 3 \% \mathrm{~B} 1 \mathrm{O}+\mathrm{de}+\text { ricardo }+\mathrm{a}}$ ngelica+liddell>.
} 
that there is no actual compensation for the wrongs inflicted on the victims of wild capitalism.

It is important to remark that El año de Ricardo, as well as other adaptations and appropriations of Richard III staged over the last few years, have been understood by audiences as an allegory of political corruption within the Spanish democratic system, Liddell's one performance being of the most unforgettable theatrical experiences regarding this issue. The number of references to Richard III in the Spanish newspapers when analysing corruption is huge. In an article published by El Confidencial soon after Liddell was awarded a Premio Nacional de Teatro (2012), Luis Bárcenas, ex-treasurer of the political party Partido Popular (PP), who was sent to prison for tax fraud and illegal payments, appears as the real counterpart of the evil character, Ricardo. ${ }^{9}$ The newspaper El Mundo, on the other hand, compares Luis Bárcenas with Shakespeare's Duke of Buckingham, as Richard III would not have been crowned without his service. ${ }^{10}$ Ignacio Urdangarín is said to be Richard III in an articled published by an online magazine ("Urdangarín is Richard III");" and Mariano Rajoy is also accused of treachery à la Richard III in a different newspaper ("Rajoy, in the same way as Shakespeare's Richard III, seems harmless at first sight"). ${ }^{12}$ Neither ex-prime minister José María Aznar ("Aznar has changed his kingdom for 120.000 euros a year"), ${ }^{13}$ nor the ex-Mayoress of Madrid Esperanza Aguirre ("My kingdom for an armchair"), have missed the chance to become Richard III. ${ }^{14}$

\footnotetext{
${ }^{9}$ Riaño, Peio H. “Angélica Liddell mantiene intactas sus lesiones incompatibles con la vida”. El Confidencial. Web. 2 Feb. 2012. <http://www.elconfidencial.com/cultura/2013-02-12/angelica-liddell-mantieneintactas-sus-lesiones-incompatibles-con-la-vida-despues-del-nacional_496521/>. ${ }^{10}$ Cuartango, Pedro G. "Luis Bárcenas. Duque de Buckingham. El mal engendra el mal". El Mundo. Web. 9 Feb. 2012. <http://quiosco.elmundo.orbyt.es/ModoTexto/PaginaNoticiaImprimir.aspx?id=1 2960533\&sec $=$ El\%20Mundo\&fecha=09 02_2013\&pla=pla_11014_Madrid\&tip $\mathrm{O}=1>$.

${ }^{11}$ Martínez, Luis. "Urdangarín es Ricardo III". Entretanto Magazine. Web. 5 Mar. 2013. <http://www.entretantomagazine.com/2013/03/05/en-tiempo-demiseria-viii-la-nave-de-los-locos/>.

${ }^{12}$ Navajas, Santiago. “Es Mariano Rajoy el temible y malvado Keyser Söze?” $\begin{array}{lllll}\text { Libertad Digital. } & \text { Web. } & 28 & \text { Sept. } & 2014 .\end{array}$ <http://www.libertaddigital.com/opinion/santiago-navajas/es-mariano-rajoy-eltemible-y-malvado-keyser-soze-73582/>.

${ }^{13}$ Martínez Soler. "Aznar ocultó el país y no cumplió el mundo". 20 Minutos. Web. $20 \quad$ June 2006.

<http://blogs.20minutos.es/martinezsoler/2006/06/29/aznar-oculto-el-pais-y-noincumplio-en-mundo/>.

${ }^{14}$ García, Eduardo . "Esperanza Aguirre: Mi reino por un sillón”. La Gaceta. Web. 9 Mar. 2015. <http://ad2ming.gaceta.es/noticias/eaguirre-ricardo-iii09032015-1114>.
} 
To conclude, this article has attempted to compare and contrast between 'nostalgic' productions of Richard III that may contribute to a process of euphemisation of current political affairs together with Angelica Liddell's radical exploration of both current politics and modes of (re)presentation on stage. Where others sing to past epic, Liddell screams satirically; where others resort to historically situated narratives, she forces anachronism. Where others provide a neat scenario, she builds a hybrid setting. Where representation governs, Liddell claims presentation: the voice and body of the actress become an essential tool, as she invests all her energy in the performance. All these elements help Liddell to challenge various notions of authority, denouncing that capitalism governs Western states and bodies even -if not especially- within (apparent) democratic structures.

\section{WORKS CITED}

Avilés, Lupita. “Angélica Liddell: Bush, Aznar, Blair eran bufones”. Swiss Info. Web. 31 Oct. 2011. <http://www.swissinfo.ch/spa/ang\%C3\%A9licaliddell---bush--aznar--blair-eran-bufones-/31469978>.

Bal, Mieke. Quoting Caravaggio, Contemporary Art, Preposterous History. Chicago: University of Chicago Press, 1999.

BBC News: Martin Freeman Gets Mixed Reviews for his Richard III. BBC News. Entertainment and Art. Web. 10 July 2014. <http://www.bbc.com/news/entertainment-arts-28243102>.

---. Actor Cumberbatch to Read Poem at Richard Reburial. BBC News. Web. 24 Mar. 2015. <http://www.bbc.com/news/uk-england-leicestershire32040692>.

Bennett, Susan. Performing Nostalgia: Shifting Shakespeare and The Contemporary Past. New York: Routledge, 1996.

Channel 4: Week of Exclusive Life Programming For Burial of King Richard III. $\begin{array}{lllll}\text { Channel } & 4 & \text { Web. } & 2 & \text { Mar. }\end{array}$ <http://www.channel4.com/info/press/news/week-of-exclusive-liveprogramming-for-burial-of-king-richard-iii >.

Cuartango, Pedro G. "Luis Bárcenas. Duque de Buckingham. El mal engendra el mal". El Mundo. Web. 9 Feb. 2012. <http://quiosco.elmundo.orbyt.es/ModoTexto/PaginaNoticiaImprimir.as px?id=12960533\&sec=El\%20Mundo\&fecha=09 02_2013\&pla=pla 11 014_Madrid\&tipo=1>.

De Barrón. "El estado nacionaliza el grupo de Bankia". El País. Web. 9 May. 2012.

<http://economia.elpais.com/economia/2012/05/09/actualidad/13365595 67_240280.html>.

Doctors of the World. Austerity and Xenophobia Creating Barriers to Health Care in Europe. Doctors of the World. Web. 9 Apr. 2013. 
<http://doctorsoftheworld.org.uk/blog/entry/austerity-and-xenophobiacreating-barriers-to-healthcare-in-europe>.

Dollimore, Jonathan, and Alan Sinfield. Political Shakespeare. New Essays in Cultural Materialism. Manchester: Manchester University Press, 1985.

García, Eduardo. "Esperanza Aguirre: Mi reino por un sillón”. La Gaceta. Web. 9 Mar. 2015. <http://ad2ming.gaceta.es/noticias/eaguirre-ricardo-iii09032015-1114>.

Jameson, Fredric. Postmodernism or the Cultural Logic of Late Capitalism. Durham: Duke University Press, 1991.

Lehmann, Courtney. "The Postnostalgic Reinassance: The 'Place' of Liverpool in Don Boyd's My Kingdom." Screening Shakespeare in the TwentyFirst Century. Ed. Mark Thornton Burnett and Ramona Wray. Edinburgh: Edinburgh University Press, 2006.

Liddell, Angélica. "El año de Ricardo". Trilogía: Actos de Resistencia contra la muerte. Bilbao: Artezblai, 2009.

---. El año de Ricardo. ARTEA: Universidad de Castilla La Mancha, $<$ http://artesescenicas.uclm.es/archivos_subidos/textos/240/angelicalidd ell_ricardo.pdf $>$.

Martínez, Luis. "Urdangarín es Ricardo III". Entretanto Magazine. Web. 5 Mar. 2013. <http://www.entretantomagazine.com/2013/03/05/en-tiempo-demiseria-viii-la-nave-de-los-locos/>.

Martínez Soler. “Aznar ocultó el país y no cumplió el mundo”. 20 Minutos. Web. 20 June 2006. <http://blogs.20minutos.es/martinezsoler/2006/06/29/aznar-oculto-elpais-y-no-incumplio-en-mundo/>.

Ministerio de Educación, Cultura y Deporte. "El año de Ricardo". YouTube. YouTube, LLC, 23 Feb. 2011. Web. Last access: 30 Nov. 2015. <https://www.youtube.com/watch?v=OxJ04PS8Rso>.

Montero, Jesús. "Prólogo". Trilogía. Actos de resistencia contra la muerte. Angélica Liddell. Bilbao: Artezblai, 2009. 5-8.

Navajas, Santiago. “¿Es Mariano Rajoy el terrible y malvado Keyser?” Libertad $\begin{array}{lllll}\text { Digital. } & \text { Web. } & 28 & \text { Sept. } & \end{array}$ <http://www.libertaddigital.com/opinion/santiago-navajas/es-marianorajoy-el-temible-y-malvado-keyser-soze-73582/>.

Percy, Martin and Peter Reynolds. "A Conversation with Sir Ian McKellen about Richard III.” Stagework. Web. Last access: Nov. 2015. <http://www.stagework.org.uk/mckellen/index.htm>.

Perkins, Anne. "Then Was The Winter of Our Discontent." $B B C$ News. Web. 5 Sept. 2008 <http://news.bbc.co.uk/2/hi/uk_news/politics/7598366.stm>.

Perry, Keith. "Kevin Spacey: Richard III look was inspired by Gadafi." The Telegraph. $\quad$ Web. $\quad 10 \quad$ June 2014. <http://www.telegraph.co.uk/culture/theatre/10888285/Kevin-SpaceyRichard-III-look-was-inspired-by-Gaddafi.html>. 
Riaño, Peio H. “Angélica Liddell mantiene intactas sus lesiones incompatibles con la vida". El Confidencial. Web. 2 Feb. 2012. <http://www.elconfidencial.com/cultura/2013-02-12/angelica-liddellmantiene-intactas-sus-lesiones-incompatibles-con-la-vida-despues-delnacional 496521/>.

Royal Shakespeare Company. "Richard III stage footage, Act 1, Scene 1, 2012, Royal Shakespeare Company." YouTube. YouTube, LLC, 23 Feb. 2011. Web. Last access: 1 June 2012. Nov. 2015. <https://www.youtube.com/watch?v=K9wzWYtYGBI>.

Sevillano, Elena G. "10.000 millones menos para sanidad”. El País. Web.14 Mar.

$<$ http://politica.elpais.com/politica/2015/03/14/actualidad/1426369300_ 405355.html>.

Shakespeare, William. Henry IV. 1597. Arden Shakespeare. Third Series. Ed. David Scott Kastan. London: Arden, 2002.

---. Richard III. 1594. Arden Shakespeare. Third Series. Ed. James R. Siemon. London: Arden, 2009.

Received: 15 September 2015

Accepted: 29 November 2015 